\title{
Efektivitas Model Pembelajaran Anchored Instruction dalam Pembelajaran Matematika Terhadap Kemampuan Berpikir Kritis Siswa
}

\author{
Sunyoto Hadi Prayitno ${ }^{1}$, Oscar Jaya Alphareno ${ }^{2}$ \\ 1,2 Program Studi Pendidikan Matematika, Fakultas Sains dan Teknologi, Universitas PGRI Adi Buana Surabaya \\ J1. Dukuh Menanggal XII, Dukuh Menaggal, Kec. Gayungan, Kota Surabaya, Jawa Timur \\ nyoto_hp@unipasby.ac.id
}

\begin{abstract}
Conventional learning with the lecture method used by some teachers of Al-Amin Junior High School Surabaya makes students' critical thinking skills less prominent. The researchers conducted research using the Anchored Instruction learning model which has the aim of determining whether or not the application of the Anchored Instruction learning model is effective in learning mathematics to students' critical thinking skills. The effectiveness of this study is viewed from 4 variables as follows: (1) teacher ability, (2) student activity, (3) student learning outcomes, and (4) student responses. The research method used in this research is descriptive quantitative research. The data collection techniques used were observation, tests, and questionnaires. The test used was an essay test which consisted of 3 questions to determine the students' critical thinking skills towards the comparison material. Based on the results of the research conducted, it is known that the teacher's ability to get a conversion value of 3.47 which is categorized as good, student activity gets a percentage of $78.89 \%$ which is active, student learning outcomes achieve classical learning completeness of $83.33 \%$, and student responses are positive. Where the percentage of student responses was $82.16 \%$ which was categorized as positive. From the results of this study, it can be concluded that the Anchored Instruction learning model in mathematics learning is effective against students' critical thinking skills.
\end{abstract}

Keywords: Effectiveness; Anchored Instruction; Mathematics; Critical Thinking

\begin{abstract}
Abstrak
Pembelajaran konvensional dengan metode ceramah yang digunakan oleh sebagian guru SMP Al-Amin Surabaya membuat kemampuan berpikir kritis siswa kurang terlihat menonjol. Maka peneliti melakukan penelitian menggunakan model pembelajaran Anchored Instruction yang memiliki tujuan untuk mengetahui efektif tidaknya penerapan model pembelajaran Anchored Instruction dalam pembelajaran matematika terhadap kemampuan berpikir kritis siswa. Keefektifan penelitian ini ditinjau dari 4 variabel sebagai berikut: (1) kemampuan guru, (2) aktivitas siswa, (3) hasil belajar siswa, dan (4) respon siswa. Metode penelitian yang digunakan dalam penelitian ini adalah penelitian kuantitatif deskriptif. Teknik pengumpulan data yang digunakan adalah observasi, tes, dan angket. Tes yang digunakan adalah tes esai yang berjumlah 3 soal untuk mengetahui kemampuan berpikir kritis siswa terhadap materi perbandingan. Berdasarkan hasil penelitian yang dilakukan, diketahui bahwa kemampuan guru mendapatkan nilai konversi 3,47 yang berkategori baik, aktivitas siswa mendapatkan persentase 78,89\% yang berkategori aktif, hasil belajar siswa mencapai ketuntasan belajar secara klasikal sebesar 83,33\%, dan respon siswa positif dimana respon siswa persentase sebesar $82,16 \%$ yang berkategori positif. Dari hasil penelitan tersebut dapat disimpulkan bahwa model pembelajaran Anchored Instruction dalam pembelajaran matematika efektif terhadap kemampuan berpikir kritis siswa.
\end{abstract}

Kata kunci: Efektivitas, Anchored Instruction, Matematika, Berpikir Kritis

Copyright (c) 2021 Sunyoto Hadi Prayitno, Oscar Jaya Alphareno

$\triangle$ Corresponding author: Sunyoto Hadi Prayitno

Email Address: nyoto_hp@unipasby.ac.id (Jl. Dukuh Menanggal XII, Dukuh Menaggal, Kec. Gayungan, Kota Surabaya) Received 27 March 2021, Accepted 05 July 2021, Published 06 July 2021

\section{PENDAHULUAN}

Menurut Undang-Undang Sistem Pendidikan Nasional (Sisdiknas) Nomor 20 Tahun 2003, pendidikan adalah usaha sadar dan terencana untuk mewujudkan suasana belajar dan proses pembelajaran agar peserta didik secara aktif mengembangkan potensi dirinya untuk memiliki kekuatan spiritual keagamaan, pengendalian diri, kepribadian, kecerdasan, akhlak mulia, serta keterampilan yang diperlukan 
dirinya, masyarakat, bangsa, dan negara. Pendidikan merupakan salah satu aspek yang penting dalam kehidupan kita dari dulu hingga saat ini. Hal ini berarti bahwa setiap manusia memiliki hak untuk mendapatkan pendidikan yang layak agar dapat mengembangkan potensi dalam dirinya. Pendidikan merupakan salah satu cara untuk membangun bangsa Indonesia. Dalam dunia pendidikan, terdapat salah satu ilmu pengetahuan yang sering disebut sebagai ibu ilmu pengetahuan yaitu ilmu matematika.

Menurut Shadiq (2014:13) matematika merupakan pola atau keteraturan. Matematika juga merupakan ilmu dasar tentang kuantitas, struktur, ruang, dan perubahan yang peranannya sangat penting dalam kehidupan sehari-hari di berbagai bidang. Belajar matematika sangat penting dan merupakan syarat cukup untuk melanjutkan ke jenjang pendidikan berikutnya. Matematika telah diajarkan mulai dari bangku taman kanak-kanak hingga perguruan tinggi untuk membekali siswa dengan kemampuan berpikir logis, analitis, sistematis, kritis, dan kreatif. Matematika digunakan untuk menyelesaikan berbagai permasalahan di kehidupan sehari-hari. Akan tetapi pada kenyataannya, banyak orang yang masih kesulitan dalam menyelesaikan permasalahan matematika sehingga menganggap bahwa matematika itu sulit.

Menurut Pritasari (2019:9) menyatakan bahwa pembelajaran merupakan serangkaian proses belajar untuk mengenal, memahami dan mendalami suatu hal. Pembelajaran bertujuan untuk membantu siswa dalam memahami konsep yang diajarkan oleh guru. Maka pembelajaran matematika adalah suatu proses pemberian pengalaman belajar kepada siswa melalui serangkaian kegiatan yang direncanakan, sehingga siswa memperoleh kemampuan mempelajari materi matematika.

Menurut Saputra (2020:2) menyatakan bahwa kemampuan berpikir kritis merupakan keterampilan berpikir yang melibatkan proses kognitif dan mengajak siswa untuk berpikir reflektif terhadap suatu permasalahan. Dalam dunia pendidikan, kemampuan berpikir kritis dapat membantu siswa dalam memahami materi yang dipelajari dengan mengevaluasi argumen secara kritis pada buku teks, teman diskusi, maupun argumentasi guru dalam kegiatan pembelajaran. Kemampuan berpikir kritis dapat digunakan untuk menyelesaikan permasalahan matematika yang ada dikehidupan sehari-hari. Membekali siswa dengan kemampuan berpikir kritis akan membantu siswa dalam menyelesaikan berbagai permasalahan matematika yang terjadi dengan memperhatikan fakta dan referensi yang ada.

Berdasarkan pengamatan peneliti, sebagian besar guru di SMP Al-Amin Surabaya masih menggunakan model pembelajaran secara konvensional. Hal ini mengakibatkan siswa menjadi jenuh, kurang aktif, monoton, kurang dapat mengembangkan kemampuan berpikir kritisnya, dan akibatnya berpengaruh terhadap hasil belajar. Kemampuan berpikir kritis siswa di SMP Al-Amin Surabaya kurang terlihat menonjol karena belum memenuhi dari indikator kemampuan berpikir kritis, yaitu interpretation, dan inference. . Hal ini diketahui peneliti pada saat siswa mengumpulkan tugas yang hanya berisi rumus, cara, dan jawaban seperti gambar 1 dibawah ini. 

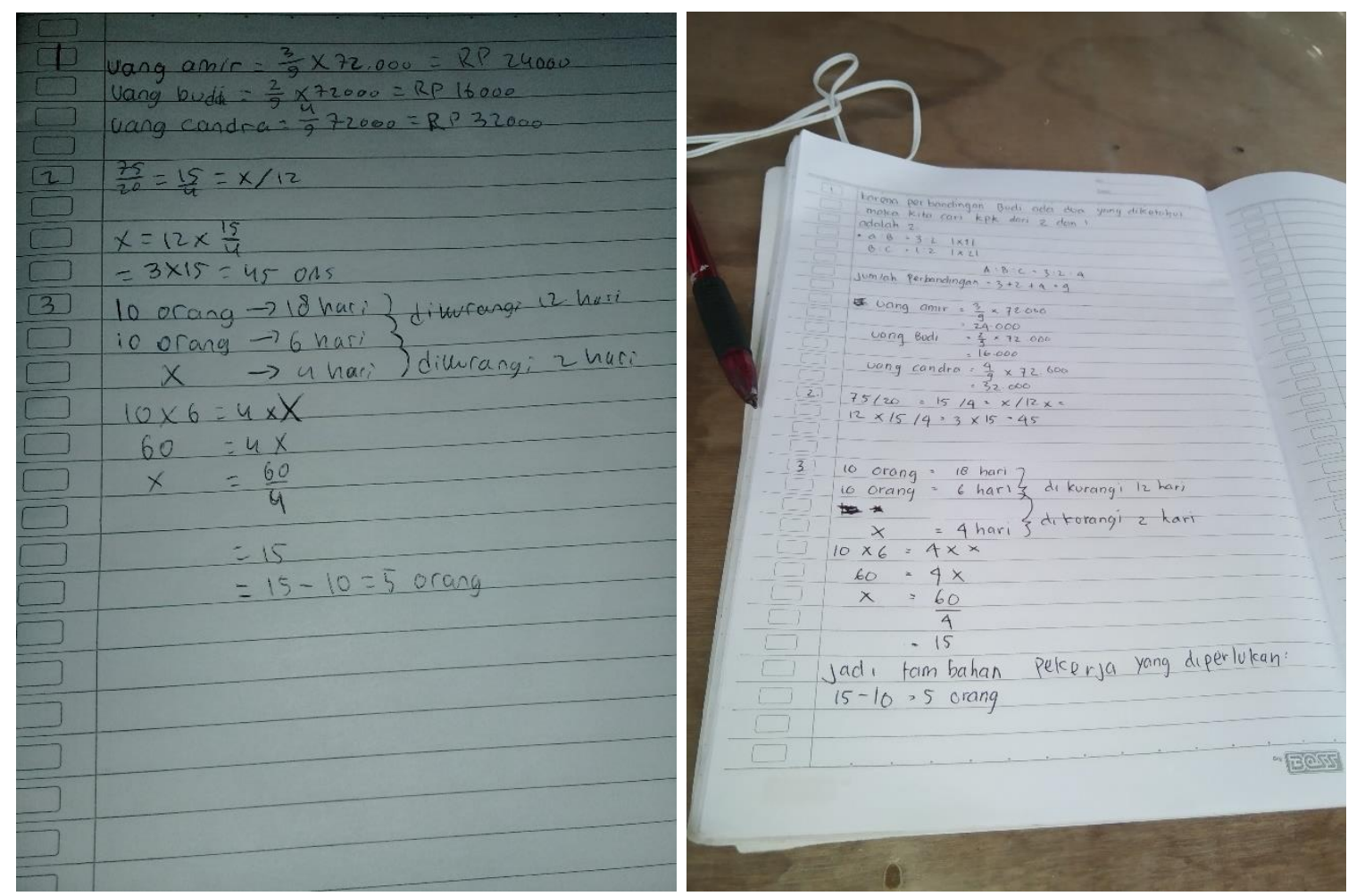

Gambar 1. Jawaban Tugas Siswa

Pengamatan pada saat guru melakasanakan proses pembelajaran, siswa terlihat kurang aktif dalam bertanya, berdiskusi, menafsirkan dan menyimpulkan. Sehingga untuk mengatasi permasalahan tersebut, guru harus memiliki model pembelajaran yang dapat meningkatkan peranan siswa dalam proses pembelajaran sehingga siswa dapat mengembangkan keterampilan bertanya, berdiskusi, menafsirkan, dan menyimpulkan. Model pembelajaran yang dapat dijadikan alternatif oleh guru dalam usaha meningkatkan kemampuan berpikir kritis siswa, salah satunya adalah model pembelajaran Anchored Instruction.

Model pembelajaran Anchored Instruction adalah model pembelajaran yang berbasis teknologi yang dikembangkan oleh The Cognition and Technology Group at Vanderbilt University yang dipimpin oleh John Bransford. Secara umum, model pembelajaran Anchored Instruction mirip dengan model pembelajaran Problem Based Learning (PBL). Perbedaan antara Problem Based Learning dengan Anchored Instruction adalah apabila dalam model pembelajaran Problem Based Learning siswa diharapkan melakukan dan mencari sumber informasi yang terkait dalam pembelajaran sendiri. Sedangkan model pembelajaran Anchored Instruction memiliki tipe menempelkan semua informasi yang diperlukan untuk pemecahan masalah dalam bentuk cerita "kasus" atau "anchor" yang telah disajikan dan menekankan pada penggunaan multmedia yang bersifat visual (Ariyanto, 2011). Kasus tersebut dapat berupa video, power point, atau teknologi multimedia interaktif lainnya. Pemberian materi dengan menampilkan suatu permasalahan yang dikemas dalam bentuk cerita dan memanfaatkan teknologi yang ada diharapkan dapat meningkatkan minat dan kemampuan berpikir kritis siswa.

Adapun penelitian yang dilakukan oleh Sidik, dkk. (2016) didapatkan hasil penelitian yaitu hasil post-test kelas kontrol yang menggunakan model pembelajaran konvensional mendapatkan rerata sebesar 
70,65. Sedangkan hasil post-test kelas eksperimen yang menggunakan model pembelajaran Anchored Instruction mendapatkan rerata sebesar 76,94. Dengan hasil tersebut, maka terdapat perbedaan antara hasil post-test kelas kontrol dan kelas eksperimen terhadap penguasaan konsep fisika dan hasil belajar siswa. Berdasarkan hasil observasi keterlaksanaan pembelajaran menggunakan model pembelajaran Anchored Instruction, mendapatkan rerata sebesar 2,87 dinyatakan termasuk dalam kategori "cukup baik" dan rerata Percentage Agreement sebesar 93,91\% dinyatakan dalam kategori "sangat reliabel". Rata-rata peningkatan hasil tes penguasaan konsep fisika siswa meningkat sebesar 58,37\% dan hasil $t_{\text {hitung }}$ adalah 4,009. Maka dapat dinyatakan bahwa penerapan model pembelajaran Anchored Instruction efektif meningkatkan penguasaan konsep fisika dan hasil belajar siswa kelas X SMA Muhammadiyah Purworejo tahun pelajaran 2015/2016. Sealin itu, berdasarkan penelitian yang dilakukan oleh Erawarni (2016) didapatkan rata-rata hasil belajar siswa dengan menggunakan model pembelajaran Anchored Instruction dengan pendekatan Quantum Learning telah memenuhi KKM yaitu lebih dari 75. Pengujian one sample ttest mendapatkan hasil ketuntasan belajar individu dengan $t_{\text {hitung }}=2,87>t_{\text {tabel }}=2,655$. Kemampuan berpikir kritis siswa mengalami peningkatan sebelum dan setelah kegiatan pembelajaran sebesar $\langle g\rangle=$ 0,57 yang dikategorikan sedang. Maka dapat disimpulkan bahwa model pembelajaran Anchored Instruction dengan pendekatan Quantum Learning efektif untuk meningkatkan kemampuan berpikir kritis siswa SMA materi efek pemanasan global.

Berdasarkan uraian latar belakang diatas, maka peneliti bermaksud melakukan penelitian yang berjudul Efektivitas Model Pembelajaran Anchored Instruction dalam Pembelajaran Matematika Terhadap Kemampuan Berpikir Kritis Siswa. Tujuan penelitian ini untuk mengetahui efektif tidaknya penerapan model pembelajaran Anchored Instruction dalam pembelajaran matematika terhadap kemampuan berpikir kritis siswa.

\section{METODE}

Jenis penelitian yang digunakan adalah kuantitatif deskriptif. Menurut Kusumaningtyas (2016:105) efektivitas pembelajaran dalam penelitian ditinjau dari ketercapaian empat aspek indikator, yaitu kemampuan guru selama kegiatan pembelajaran berkategori baik, aktivitas siswa selama kegiatan pembelajaran berkategori aktif, hasil belajar seluruh atau setidaknya $80 \%$ dari jumlah siswa telah mencapai nilai $\geq 75$, dan respon siswa setelah kegiatan pembelajaran berkategori positif. Peneliti akan memberikan model pembelajaran Anchored Instruction dalam pembelajaran matematika terhadap kemampuan berpikir kritis dengan materi perbandingan. Penelitian ini menggunakan Pre-Experimental Designs (Nodesigns) berupa One-Shot Case Study. Suatu kelompok diberi treatment atau perlakuan terlebih dahulu, dan selanjutnya hasil tersebut diobservasi. Desain penelitian ini dapat digambarkan sebagai berikut:

$$
X \rightarrow O
$$

Keterangan:

$\mathrm{X}=$ Perlakuan yang diberikan berupa model pembelajaran Anchored Instruction secara daring. 
$\mathrm{O}=$ Hasil tes setelah melalui proses pembelajaran (posttest).

\section{Populasi dan Sampel}

Penelitian ini dilaksanakan di SMP Al-Amin Surabaya dengan menerapkan pembelajaran secara daring. Populasi adalah wilayah generalisasi yang terdiri atas obyek/subyek yang mempunyai kualitas dan karakteristik tertentu yang diterapkan oleh peneliti untuk dipelajari dan kemudian ditarik kesimpulannya. Jadi, populasi merupakan subjek dari keseluruhan penelitian (Sugiyono, 2015: 80). Populasi dalam penelitian ini adalah seluruh siswa SMP Al-Amin Surabaya. Sampel adalah bagian dari jumlah dan karakteristik yang dimiliki oleh populasi tersebut (Sugiyono, 2015: 81). Sampel yang digunakan yaitu siswa kelas VII-C yang berjumlah 34 siswa.

\section{Teknik Pengumpulan Data}

Teknik pengumpulan data yang digunakan dalam penelitian ini adalah metode observasi, metode tes, dan metode angket. Metode observasi digunakan untuk mengumpulkan data mengenai kemampuan guru selama kegiatan pembelajaran, dan aktivitas siswa selama kegiatan pembelajaran. Pada observasi kemampuan guru, peneliti bertindak sebagai pengajar dan guru pamong sebagai observer. Untuk observasi aktivitas siswa, peneliti memilih lima siswa secara acak untuk menjadi subjek pengamatan dan observer mencatat kode/nomor sesuai dengan indikator lembar observasi aktivitas siswa. Metode tes digunakan untuk mengumpulkan data mengenai hasil belajar siswa setelah mengikuti kegiatan pembelajaran. Tes yang digunakan dalam penelitian ini adalah berbentuk esai yang berjumlah 3 soal dengan materi perbandingan melalui media Google Form. Metode angket digunakan untuk mengumpulkan data mengenai seberapa besar respon siswa terhadap pembelajaran matematika dengan menggunakan model pembelajaran Anchored Instruction yang berupa daftar pernyataan. Pengisian lembar angket dilakukan oleh siswa dengan memilih pilihan "setuju" atau "tidak setuju" sesuai dengan apa yang siswa rasakan.

\section{Analisis Data}

Dalam penelitian ini, data yang terkumpul dalam bentuk angka kemudian dihitung dalam bentuk persentase lalu dideskripsikan ke dalam kalimat.

\section{Analisis Data Kemampuan Guru}

Hasil data kemampuan guru selama kegiatan pembelajaran dianalisis dengan cara mencari rata-rata dari tiap aspek dalam pertemuan yang dilakukan. Adapun tabel kategori penilaian kemampuan guru selama kegiatan pembelajaran adalah sebagai berikut:

Tabel 1. Kategori Kemampuan Guru

\begin{tabular}{|c|c|}
\hline Penilaian Kemampuan Guru & Kategori \\
\hline $0,00 \leq$ nilai $<1,50$ & Kurang Baik \\
\hline $1,50 \leq$ nilai $<2,50$ & Cukup Baik \\
\hline $2,50 \leq$ nilai $<3,50$ & Baik \\
\hline $3,50 \leq$ nilai $<4,00$ & Sangat Baik \\
\hline
\end{tabular}

Suatu pembelajaran dikatakan efektif apabila kemampuan guru selama kegiatan pembelajaran mencapai 
Efektivitas Model Pembelajaran Anchored Instruction dalam Pembelajaran Matematika Terhadap Kemampuan Berpikir Kritis Siswa, Sunyoto Hadi Prayitno, Oscar Jaya Alphareno

kategori baik

\section{Analisis Data Aktivitas Siswa}

Analisis data aktivitas dihitung menggunakan persentase. Adapun tabel persentase kategori untuk menyatakan aktivitas siswa adalah sebagai berikut:

Tabel 2. Kategori Aktivitas Siswa

\begin{tabular}{|c|c|}
\hline Persentase Aktivitas Siswa & Kategori \\
\hline $0 \% \leq P A S<20 \%$ & Sangat Kurang Aktif \\
\hline $20 \% \leq P A S<40 \%$ & Kurang Aktif \\
\hline $40 \% \leq P A S<60 \%$ & Cukup Aktif \\
\hline $60 \% \leq P A S<80 \%$ & Aktif \\
\hline $80 \% \leq P A S<100 \%$ & Sangat Aktif \\
\hline
\end{tabular}

Keterangan:

PAS $=$ Persentase aktivitas siswa

Siswa dikategorikan aktif apabila jumlah persentase rata-rata selama satu kali pertemuan lebih dari sama dengan $60 \%$.

\section{Analisis Data Hasil Belajar Siswa}

Penilaian hasil belajar dalam penelitian ini menggunakan indikator kemampuan berpikir kritis (Indira dkk., 2018:63), sebagai berikut:

1. Interpretation, yaitu memahami masalah yang ditunjukkan dengan menuliskan diketahui dan ditanyakan dari soal tersebut dengan tepat.

2. Analysis, yaitu mengidentifikasi hubungan antara pernyataan-pernyataan dan konsep-konsep yang diberikan dalam soal.

3. Evaluation, yaitu menggunakan cara yang tepat dalam menyelesaikan soal, serta melakukan perhitungan dengan lengkap dan benar.

4. Inference, yaitu membuat kesimpulan dengan tepat.

Untuk mengetahui persentase ketuntasan belajar secara klasikal, maka dapat menggunakan rumus sebagai berikut:

$$
K B K=\frac{T}{S} \times 100 \%
$$

Keterangan:

$\mathrm{KBK}=$ Persentase ketuntasan belajar secara klasikal

$\mathrm{T}=$ Jumlah siswa yang tuntas

$\mathrm{S}=$ Jumlah siswa keseluruhan

Siswa dikatakan tuntas apabila siswa mendapatkan nilai $\geq 75$. Suatu kelas dikatakan tuntas belajar apabila persentase ketuntasan belajar secara klasikal $\geq 80 \%$.

\section{Analisis Data Respon Siswa}

Data respon siswa terhadap pembelajaran matematika dalam penelitian ini meliputi respon positif dan respon negatif dengan menggunakan skala setuju dan tidak setuju. Adapun tabel persentase kategori untuk 
menyatakan respon siswa adalah sebagai berikut:

Tabel 3. Kategori Respon Siswa

\begin{tabular}{|c|c|}
\hline Persentase Respon Siswa & Kategori \\
\hline$P R S<50 \%$ & Tidak Positif \\
\hline $50 \% \leq P R S<70 \%$ & Kurang Positif \\
\hline $70 \% \leq P R S<85 \%$ & Positif \\
\hline$P R S \geq 85 \%$ & Sangat Positif \\
\hline
\end{tabular}

Keterangan:

PRS $=$ Persentase respon siswa

Respon siswa dapat dikatakan positif apabila persentase respon siswa yang memberikan respon positif sebesar $\geq 70 \%$ dalam satu kelas.

\section{HASIL DAN DISKUSI}

Tujuan dari penelitian ini adalah untuk mengetahui efektif tidaknya model pembelajaran Anchored Instruction dalam pembelajaran matematika terhadap kemampuan berpikir kritis siswa. Dalam penelitian ini, kemampuan berpikir kritis siswa dilihat dari aspek kemampuan guru selama kegiatan pembelajaran, aktivitas siswa selama kegiatan pembelajaran, dan jawaban tes hasil belajar siswa.

Data tentang efektivitas model pembelajaran Anchored Instruction terhadap kemampuan berpikir kritis siswa dipaparkan dan dideskripsikan dari beberapa aspek berikut ini, yaitu :

\section{Kemampuan Guru Selama Kegiatan Pembelajaran}

Kemampuan guru adalah potensi atau kesanggupan yang dikuasasi guru untuk melakukan suatu aktivitas atau kegiatan (Jusnarti, 2014: 8). Pada kemampuan guru dalam kegiatan pembelajaran terdapat beberapa aspek yang dinilai. Berikut adalah hasil dari observasi yang dilakukan oleh guru pamong dalam menilai kemampuan mengajar peneliti yang disajikan dalam tabel 4 .

Tabel 4. Hasil Observasi Kemampuan Guru Selama kegiatan Pembelajaran

\begin{tabular}{|c|c|c|}
\hline No. & \multicolumn{1}{|c|}{ Aspek yang Diamati } & Skor \\
\hline 1. & Pelaksanaan & 9 \\
\hline & a. Pendahuluan & 48 \\
\hline & b. Kegiatan Inti & 9 \\
\hline & c. Penutup & 13 \\
\hline 2. & Pengelolaan Waktu & 12 \\
\hline 3. & Suasana Kelas & $\mathbf{9 1}$ \\
\hline \multicolumn{2}{r}{ Jumlah } \\
\hline
\end{tabular}

Berdasarkan tabel 4 diatas, diketahui bahwa jumlah skor yang didapat oleh peneliti dalam observasi kemampuan guru dalam kegiatan pembelajaran adalah 91 dari total keseluruhan skor yaitu 105. Dengan demikian dapat dicari nilai konversinya yaitu sebagai berikut:

$$
\begin{aligned}
\text { nilai } & =\frac{\text { Jumlah skor yang didapat }}{\text { Total keseluruhan skor }} \times 4 \\
& =\frac{91}{105} \times 4
\end{aligned}
$$


Efektivitas Model Pembelajaran Anchored Instruction dalam Pembelajaran Matematika Terhadap Kemampuan Berpikir Kritis Siswa, Sunyoto Hadi Prayitno, Oscar Jaya Alphareno

$$
=3,47
$$

Nilai konversi yang diperoleh peneliti yaitu 3,47 dimana nilai tersebut diantara 2,50 $\leq$ nilai $<3,50$. Maka kemampuan guru dalam mengelola pembelajaran termasuk dalam kategori baik. Guru menggunakan model pembelajaran Anchored Instruction dikarenakan model pembelajaran tersebut dapat membuat siswa memunculkan kemampuan berpikir kritisnya. Model pembelajaran Anchored Instruction mengharuskan siswa untuk mengamati dan mencatat semua kata kunci, data, dan fakta dari media pembelajaran video yang disajikan oleh guru. Selanjutnya siswa harus menghubungkan kata kunci, data, dan fakta tersebut dengan literatur atau sumber belajar yang ada untuk mengembangkan solusi dari permasalahan yang disajikan. Setelah mendapatkan solusi dari permasalahan tersebut, maka ditarik kesimpulan berdasarkan fakta dan solusi yang didapatkan. Hal ini secara tidak langsung membuat siswa untuk memunculkan kemampuan berpikir kritisnya.

\section{Aktivitas Siswa Selama Kegiatan Pembelajaran}

Menurut Kompri (2017: 14), aktivitas siswa adalah suatu kegiatan yang menyebabkan seseorang belajar. Data aktivitas siswa ini berdasarkan kegiatan yang dilakukan siswa selama kegiatan pembelajaran daring berlangsung. Berikut adalah data hasil aktivitas yang telah diringkas pada tabel 5 .

Tabel 5. Hasil Observasi Aktivitas Siswa Selama Mengikuti Pembelajaran

\begin{tabular}{|c|l|c|}
\hline No. & \multicolumn{1}{|c|}{ Indikator Aktivitas Siswa } & Persentase \\
\hline 1 & $\begin{array}{l}\text { Mendengarkan dan memperhatikan penjelasan guru dalam proses } \\
\text { pembelajaran }\end{array}$ & $13,33 \%$ \\
\hline 2 & Memperhatikan dan menyimak video yang disajikan & $7,78 \%$ \\
\hline 3 & Membaca/memahami buku/lks yang diberikan guru & $5,56 \%$ \\
\hline 4 & Berdiskusi antar sesama teman/guru pada proses pembelajaran & $8,89 \%$ \\
\hline 5 & Menyelesaikan solusi dari permasalahan di video yang disajikan & $3,33 \%$ \\
\hline 6 & Mempresentasikan hasil pekerjaan & $2,22 \%$ \\
\hline 7 & Bertanya dan mengemukakan pendapat & $3,33 \%$ \\
\hline 8 & Menyalin/mencatat pembelajaran yang diajarkan & $7,78 \%$ \\
\hline 9 & Menjawab soal tes/kuis yang diberikan oleh guru secara individu & $25,56 \%$ \\
\hline 10 & Menyimpulkan tentang materi pembelajaran & $1,11 \%$ \\
\hline 11 & Perilaku yang tidak relevan dengan kegiatan belajar mengajar & $21,11 \%$ \\
\hline & Jumlah & $\mathbf{1 0 0 \%}$ \\
\hline
\end{tabular}

Berdasarkan hasil analisis aktivitas siswa selama kegiatan pembelajaran dapat diketahui bahwa terdapat aktivitas siswa yang relevan dan aktivitas siswa yang tidak relevan. Dalam pembelajaran, aktivitas siswa yang relevan adalah sebagai berikut:

1. Mendengarkan dan memperhatikan penjelasan guru dalam proses pembelajaran

2. Memperhatikan dan menyimak video yang disajikan

3. Membaca/memahami buku/lks yang diberikan guru

4. Berdiskusi antar sesama teman/guru pada proses pembelajaran

5. Menyelesaikan solusi dari permasalahan di video yang disajikan 
6. Mempresentasikan hasil pekerjaan

7. Bertanya dan mengemukakan pendapat

8. Menyalin/mencatat pembelajaran yang diajarkan

9. Menjawab soal tes/kuis yang diberikan oleh guru secara individu

10. Menyimpulkan tentang materi pembelajaran

Berdasarkan tabel 5, dapat diketahui bahwa aktivitas siswa yang tergolong aktif sebesar 78,89\% dan aktivitas yang tergolong tidak relevan sebesar $21,11 \%$. Hal ini menunjukkan bahwa aktivitas siswa selama kegiatan pembelajaran berada pada kategori aktif karena telah memenuhi rentang skor $60 \% \leq$ aktivitas siswa.

\section{Hasil Belajar Siswa}

Hasil belajar merupakan hasil yang menunjukkan kemampuan seseorang siswa dalam menguasai bahan pelajaranannya (Prayitno \& Muttaqien, 2018: 49). Tes hasil belajar ini ini digunakan sebagai tolok ukur untuk mengetahui kemampuan berpikir kritis siswa mengenai materi perbandingan dengan model pembelajaran Anchored Instruction. Secara ringkas tentang hasil belajar siswa disajikan pada grafik dibawah ini.

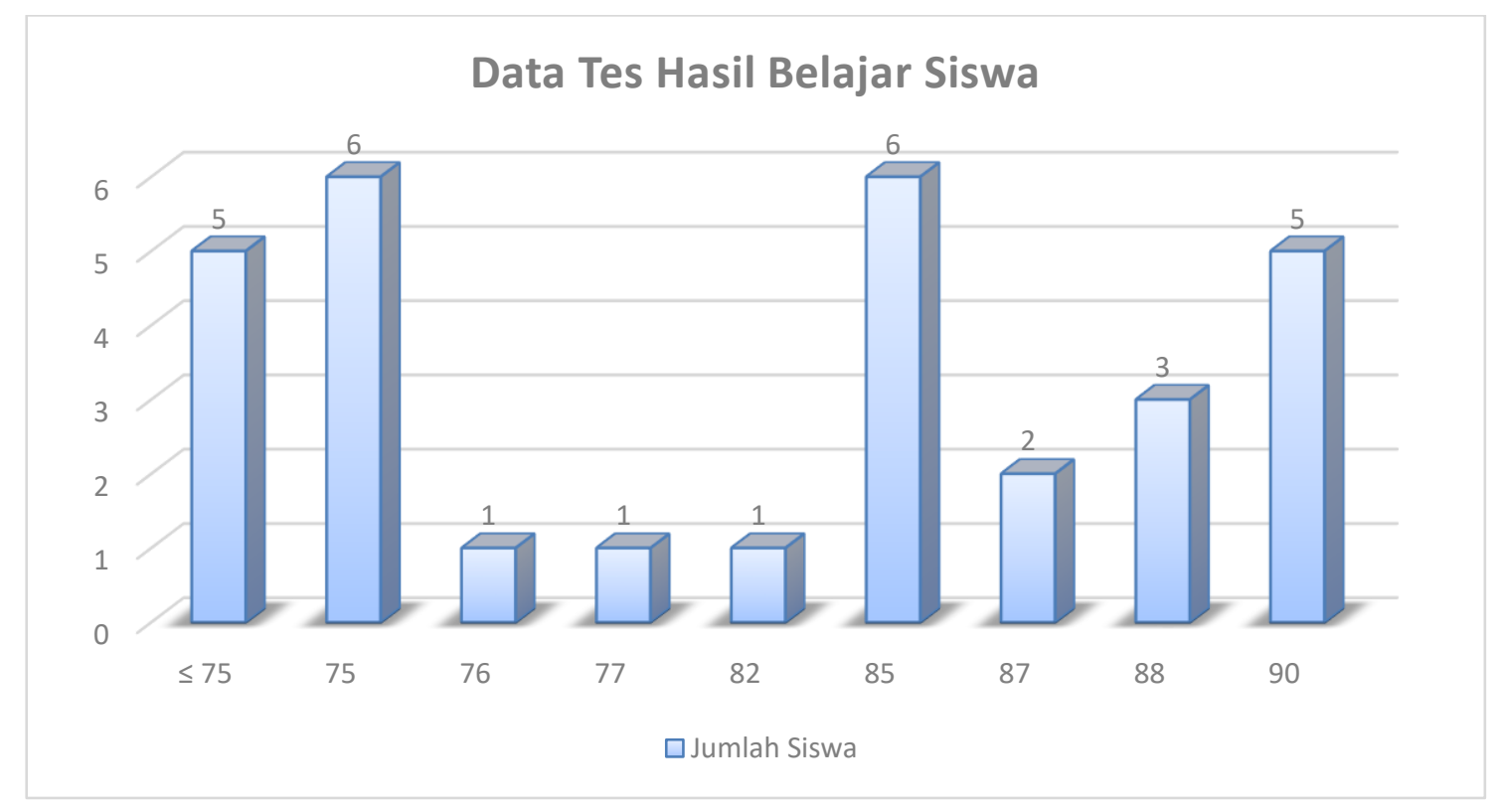

Gambar 2. Data Tes Hasil Belajar Siswa

Berdasarkan gambar 1 diatas dapat dilihat bahwa jumlah siswa yang memperoleh skor $\geq 75$, atau skor yang telah mencapai ketuntasan belajar berjumlah 25 siswa. Dengan demikian dapat dihitung persentase siswa yang tuntas atau memperoleh skor $\geq 75$ adalah sebagai berikut:

$$
\begin{gathered}
\text { KBK }=\frac{T}{S} \times 100 \% \\
=\frac{25}{30} \times 100 \% \\
=83,33 \%
\end{gathered}
$$

Karena persentase siswa yang mencapai nilai $\geq 75$ pada tes hasil belajar adalah $83,33 \%$ maka dapat 
dikatakan bahwa ketuntasan hasil belajar siswa tuntas secara klasikal telah tercapai. Dari hasil tes yang dikirimkan kepada peneliti, sebagian besar siswa menuliskan diketahui, ditanya, jawab, dan kesimpulan. Hal ini menunjukkan bahwa siswa kelas VII-C mencari fakta-fakta, kata kunci, dan data terlebih dahulu yang ditulis pada "diketahui". Setelah diketahui fakta dan data yang terdapat dalam permasalahan tersebut, siswa mencari apa yang ditanyakan dalam permasalahan tersebut yang ditulis pada "ditanya". Maka dapat diketahui bahwa siswa kelas VII-C memahami masalah dari soal tersebut. Selanjutnya siswa menuliskan "jawab" dan membuat model matematika berdasarkan dari apa yang diketahui dalam soal tersebut serta menuliskan rumus yang sesuai untuk menyelesaikan permasalahan tersebut. Maka dapat diketahui bahwa siswa kelas VII-C mengidentifikasi hubungan antara pernyataan dan konsep yang diberikan dalam soal. Tahap berikutnya siswa mengembangkan solusi jawaban dengan sudut pandangnya masing-masing. Hal ini menunjukkan bahwa siswa kelas VII-C menggunakan cara berdasarkan rumus yang telah dituliskan dan melakukan perhitungan sesuai sudut pandangnya masing-masing. Penarikan kesimpulan dilakukan pada saat siswa telah menyelesaikan permasalahan tersebut yang dituliskan siswa pada akhir jawaban dengan awalan "jadi”. Berdasarkan uraian tersebut, dapat dikatakan bahwa siswa kelas VII-C telah memenuhi indikator kemampuan berpikir kritis siswa yaitu memahami masalah, mengidentifikasi hubungan, mengembangkan solusi, dan penarikan kesimpulan.

\section{Respon Siswa}

Menurut Poerwadarminta dalam Kusuma dkk. (2017: 5), respon siswa berarti reaksi atau tanggapan yaitu penerimaan atau penolakan, serta sikap acuh tak acuh terhadap apa yang disampaikan oleh komunikator dalam pesannya. Data diambil dengan format respon siswa berupa angket yang dimasukkan ke dalam Google Form lalu disebarkan melalui Google Classroom. Respon siswa ini digunakan untuk mengukur seberapa besar respon siswa terhadap pembelajaran matematika dengan menggunakan model pembelajaran Anchored Instruction. Data respon siswa yang diperoleh dari kelas VII-C SMP Al-Amin Surabaya adalah sebagai berikut:

\section{Data Respon Siswa}

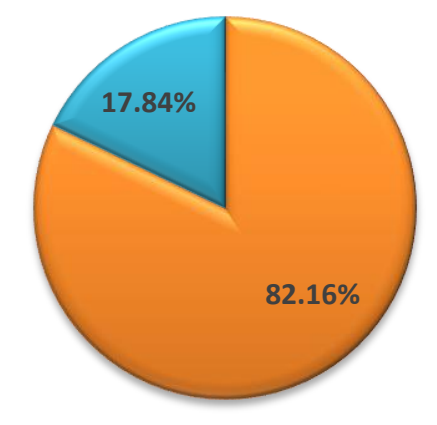

$\square$ Respon Positif $\quad \square$ Respon Negatif

Gambar 3. Data Hasil Respon Siswa 
Dari hasil analisis data respon siswa setelah mengikuti kegiatan pembelajaran yang telah dihitung sedemikian rupa diperoleh bahwa siswa SMP Al-Amin Surabaya kelas VII-C menyatakan model pembelajaran Anchored Instruction dalam pembelajaran matematika terhadap kemampuan berpikir kritis siswa banyak yang merespon positif. Persentase rata-rata seluruh jawaban siswa yang merespon positif sebesar $82,16 \%$ dan yang memberi respon negatif sebesar $17,84 \%$. Karena rata-rata respon siswa yang menjawab positif mendapatkan persentase $82,16 \%$, dan berada pada lingkup $70 \% \leq P R S<80 \%$ maka respon siswa setelah mengikuti kegiatan pembelajaran termasuk dalam kategori positif.

\section{KESIMPULAN}

Berdasarkan hasil penelitian dan pembahasan yang telah diuraikan sebelumnya, maka dapat disimpulkan bahwa model pembelajaran Anchored Instruction dalam pembelajaran matematika efektif terhadap kemampuan berpikir kritis siswa. Keefektifan model pembelajaran ini berdasarkan kemampuan guru memperoleh nilai konversi 3,47 yang termasuk dalam kategori baik, aktivitas siswa memperoleh persentase sebesar $78,89 \%$ yang termasuk dalam kategori aktif, ketuntasan hasil belajar telah tercapai dengan persentase sebesar $83,33 \%$, dan respon siswa memperoleh persentase sebesar $82,16 \%$ yang termasuk dalam kategori positif.

Dengan adanya penelitian ini, diharapkan dapat memberikan masukan bagi guru atau calon guru untuk menerapkan model pembelajaran Anchored Instruction sebagai salah satu alternatif, karena model pembelajaran ini efektif untuk memunculkan kemampuan berpikir kritis siswa. Kepada calon peneliti lainnya, diharapkan dapat mengembangkan penelitian ini ke arah yang lebih luas lagi dan mengarah terhadap perbaikan penelitian ini sehingga dapat bermanfaat bagi dunia pendidikan.

\section{REFERENSI}

Ariyanto, L. (2011). Pengembangan Perangkat Pembelajaran Matematika Model Berjangkar (Anchored Instruction) Materi Luas Kubus dan Balok Kelas VIII. Aksioma: Jurnal Matematika Dan Pendidikan Matematika UPGRIS Semarang, 2(2).

Erawarni, D. (2016). Keefektifan Model Pembelajaran Anchored Instruction Dengan Pendekatan Quantum Learning Untuk Meningkatkan Kemampuan Berpikir Kritis Siswa Sma. Skripsi. Universitas Negeri Semarang.

Indira, T., Somakim, S., \& Susanty, E. (2018). Kemampuan Berpikir Kritis Siswa SMP Melalui Pendekatan Pendidikan Matematika Realistik Indonesia. HISTOGRAM: Jurnal Pendidikan Matematika, 1(2), 61-75. DOI: https://doi.org/10.31100/histogram.v1i2.25

Jusnarti. (2014). Kemampuan Guru Ekonomi dalam Meningkatkan Disiplin Belajar Siswa pada Mata Pelajaran Ekonomi di Sekolah Menengah Atas Negeri 1 Pangean Kabupaten Kuantan Singingi. Skripsi. Universitas Islam Negeri Sultan Syarif Kasim Riau.

Kompri. (2017). Belajar; Faktor-faktor yang Mempengaruhinya. Yogyakarta: Media Akademi.

Kusuma, A., Candramila, W., \& Ariyati, E. (2017). Respon Siswa Terhadap Pembelajaran Berbasis 
Efektivitas Model Pembelajaran Anchored Instruction dalam Pembelajaran Matematika Terhadap Kemampuan Berpikir

Masalah pada Materi Pencemaran Lingkungan di Kelas X SMA. Jurnal Pendidikan Dan Pembelajaran Untan, 6(10).

Kusumaningtyas, W. (2016). Efektivitas Metode Inquiry Terhadap Hasil Belajar Matematika Siswa. Jurnal E-DuMath, 2(1), 102-108.

Prayitno, S. H., \& Muttaqien, S. (2018). Upaya Meningkatkan Hasil Belajar Matematika Siswa Kelas VIII-F SMP Negeri 22 Surabaya Melalui Penerapan Model Pembelajaran Problem Based Learning Tahun Pelajaran 2018-2019. Jurnal Edukasi, 4(2), 43-54.

Pritasari, E. (2019). Efektivitas Strategi Learning Start With A Question (LSQ) dalam Pembelajaran Matematika. Skripsi. Universitas PGRI Adi Buana Surabaya.

Saputra, H. (2020). Kemampuan Berfikir Kritis Matematis. Perpustakaan IAI Agus Salim, 1-7.

Shadiq, F. (2014). Pembelajaran Matematika: Cara Meningkatkan Kemampuan Berpikir Siswa. Yogyakarta: GRAHA ILMU.

Sidik, A. I., Ashari, H., \& Maftukhin, H. A. (2016). Efektivitas Model Pembelajaran Anchored Instruction (AI) terhadap Penguasaan Konsep Fisika dan Hasil Belajar Siswa Kelas X SMA Muhammadiyah Purworejo Tahun Pelajaran 2015/2016. Radiasi, 9(2), 59-64.

Sugiyono. (2015). Metode Penelitian Kuantitatif, Kualitatif, dan R\&D (22nd ed.). Bandung: CV. ALFABETA. 